\title{
ARTIKELEN
}

\section{Het effect van een pro Justitia-rapportage op de bewijsbeslissing: een empirische verkenning}

\author{
Roosmarijn van Es, Janne van Doorn, Jan de Keijser \& Maarten Kunst
}

Sinds de zaak Anne Faber ${ }^{1}$ in 2017 wordt in de media, maar ook in de wetenschap, nog meer aandacht besteed aan de rol die gedragskundige rapportages spelen bij rechterlijke beslissingen. In ongeveer een derde van de strafzaken voor de meervoudige kamer is behoefte aan een gedragskundige rapportage over een verdachte. Deze rapportage wordt ook wel pro Justitia (PJ)-rapportage genoemd. ${ }^{2}$ Een PJ-rapportage wordt opgesteld door een gedragskundige, dat wil zeggen een psycholoog en/of psychiater en in sommige zaken een milieuonderzoeker. Door middel van een PJ-rapportage wordt de rechter onder andere geïnformeerd over (1) een mogelijke psychische stoornis bij een verdachte (art. 39 Wetboek van Strafrecht (Sr)), (2) de mogelijke doorwerking van een stoornis op het ten laste gelegde delict, (3) het bijbehorende recidiverisico, (4) advies over toerekeningsvatbaarheid en (5) advies over mogelijke sancties. ${ }^{3}$ De aanwezigheid en de inhoud van een PJ-rapportage kan belangrijke consequenties hebben voor de verdachte, omdat het inzicht dat het biedt in de psychische gesteldheid van de verdachte implicaties kan hebben voor de op te leggen straf en/of maatregel. Deze rapportage kan bijvoorbeeld tot gevolg hebben dat de maatregel terbeschikkingstelling met dwangverpleging opgelegd wordt. Daarvoor zijn PJ-rapportages van twee gedragskundigen (waaronder een psychiater) nodig (art. 37 jo. 37a Sr). Daarnaast kan de aanwezigheid van een stoornis ten tijde van het delict leiden tot verminderde toerekening en vervolgens als strafverminderende omstandigheid in de straftoemeting worden meegenomen. ${ }^{4}$ De informatie uit een PJ-rapportage kan aldus een belangrijke rol spelen bij rechterlijke beslissingen over verwijtbaar-

1 Anne Faber raakte op 29 september 2017 tijdens een fietstocht in de buurt van Soest vermist. Twee weken later werd haar lichaam bij Zeewolde gevonden. Ze bleek verkracht te zijn en opzettelijk om het leven te zijn gebracht. De dader was Michael P., die ten tijde van het misdrijf op de Forensisch Psychiatrische Afdeling in Den Dolder verbleef vanwege eerdere gewelds- en zedenmisdrijven. Het feit dat Michael P. die bewuste 29 september 2017 vrij rondliep, veroorzaakte veel maatschappelijk verontwaardiging. Michael P. weigerde eerder namelijk medewerking aan een gedragskundig onderzoek. Mede om die reden kreeg P. geen tbs (met dwangverpleging) opgelegd. Zie voor een analyse van wat er gebeurd is het rapport van de Onderzoeksraad voor Veiligheid 2019.

2 Nederlandse Vereniging voor Psychiatrie 2013. In 2019 waren dit ongeveer 3000 rapportages, waarvan 203 klinische rapportages (Nederlands Instituut voor Forensische Psychiatrie en Psychologie Jaarbericht 2019).

3 Nederlands Instituut voor Forensische Psychiatrie en Psychologie 2016. Nederlandse Vereniging voor Psychiatrie 2013.

4 Dat hoeft niet altijd het geval te zijn: zie het Zwarte Ruiter-arrest (HR 10 september 1957, ECLI:NL:HR:1957:2) en Claessen \& De Vocht 2012. 
heid en straftoemeting. In de overige beslissingen van het beslismodel van artikel $350 \mathrm{~Sv},{ }^{5}$ komt de informatie in een PJ-rapportage niet of nauwelijks aan bod. ${ }^{6}$ De informatie uit een PJ-rapportage is irrelevant voor de bewijsbeslissing en zou formeel gezien geen rol moeten spelen in deze beslissing. Een psychische stoornis bij een verdachte ten tijde van het ten laste gelegde staat immers los van de waardering van bewijsmiddelen om tot een bewezenverklaring te komen. ${ }^{7}$ Tot op heden is weinig bekend over of de rechter zich, wellicht onbewust, laat leiden door de informatie (over het bestaan van een stoornis) uit PJ-rapportages bij het nemen van de bewijsbeslissing. De mogelijke invloed van informatie in een PJ-rapportage op de bewijsbeslissing kan ontstaan bij overtuiging van de rechter. Volgens de richtlijn van de Nederlandse Vereniging voor Psychiatrie dient informatie over een psychische stoornis bij een verdachte ten tijde van het ten laste gelegde geen op zichzelf staand onderdeel van de bewijsvoering te vormen. ${ }^{8}$ Om een mogelijk ongewenste invloed te voorkomen, leidt dat in de praktijk in veel gevallen tot formuleringen in rapportages als: 'Ten tijde van het plegen van het tenlastegelegde - indien bewezen - leed onderzochte aan een ziekelijke stoornis / gebrekkige ontwikkeling van zijn geestvermogens'. ${ }^{9}$ Ondanks het relatief hoge aantal PJ-rapportages in de strafrechtsketen, is empirisch onderzoek naar de invloed daarvan op rechterlijke beslissingen in Nederland schaars. Deze studie tracht in deze leemte te voorzien. Het doel van de huidige studie en de onderzoeksvraag die hierin centraal staat, is om door middel van een experiment onder studenten te onderzoeken in hoeverre en op welke wijze de aanwezigheid van een PJ-rapportage en informatie over een psychische stoornis invloed kan hebben op de bewijsbeslissing. In dit kader wordt hierna specifiek aandacht besteed aan psychologische verklaringen en twee theoretische modellen waarbinnen een dergelijke invloed geduid kan worden: het story model en het model van coherence-based reasoning.

5 Art. 350 Wetboek van Strafvordering: Indien het onderzoek in artikel 348 bedoeld, niet leidt tot toepassing van artikel 349, eerste lid, beraadslaagt de rechtbank op den grondslag der telastlegging en naar aanleiding van het onderzoek op de terechtzitting over de vraag of 1) bewezen is dat het feit door den verdachte is begaan, en, zoo ja, 2) welk strafbaar feit het bewezen verklaarde volgens de wet oplevert; indien wordt aangenomen dat het feit bewezen en strafbaar is, dan beraadslaagt de rechtbank over 3) de strafbaarheid van den verdachte en 4) over de oplegging van straf of maatregel, bij de wet bepaald.

6 In één specifieke situatie kan de informatie uit een PJ-rapportage ook relevant zijn voor de bewijsbeslissing, namelijk wanneer daaruit blijkt dat de verdachte geen enkel inzicht had in het eigen handelen. In deze situatie kan opzet niet worden bewezen, zie het Tolbert-arrest (HR 9 december 2008, ECLI:NL:HR:2008:BD2775).

7 Volgens het negatief-wettelijk bewijsstelsel dat in Nederland van toepassing is, mag de rechter enkel veroordelen indien is voldaan aan een minimum van wettig bewijs (art. $339 \mathrm{~Sv}$ ), maar is niet verplicht te veroordelen indien hij ondanks het bewijs niet overtuigd is (art. $338 \mathrm{~Sv}$ ). Dubelaar 2014, p. 200.

8 Nederlandse Vereniging voor Psychiatrie 2013.

9 Van Esch 2012, p. 290. 


\section{Theoretisch kader}

De informatie in een PJ-rapportage zou dus formeel geen rol moeten spelen in de bewijsbeslissing. Bij het nemen van beslissingen in onzekerheid kan dergelijke irrelevante persoonsinformatie echter doorwerken in die beslissingen via (psychologische) denkfouten, bias en heuristieken. ${ }^{10}$ Beslissingen over bewijs en schuld zijn bij uitstek beslissingen die een bepaalde mate van onzekerheid kennen. Immers, in het strafproces kan de feitelijke toedracht, of materiële waarheid, nooit met absolute zekerheid worden vastgesteld. ${ }^{11}$ De mate van onzekerheid wordt groter als sprake is van een ontkennende verdachte en er weinig aanvullend bewijs is, in tegenstelling tot klip-en-klare zaken met een overvloed aan wettige en overtuigende bewijsmiddelen en een bekennende verdachte. Bij beslissingen in onzekerheid zijn individuen (en dus ook mogelijk de rechter) geneigd om af te gaan op eerdere ervaringen en intuïtie om tot een passende bewijsconstructie te komen. ${ }^{12}$ Beslissingen komen dan op een meer holistische wijze tot stand. ${ }^{13}$ Een eerste model dat uitgaat van een dergelijke holistische wijze van bewijswaardering is het story model. ${ }^{14}$

\section{Story model}

Het story model (zie figuur 1) gaat ervan uit dat complexe beslissingen met een bepaalde mate van onzekerheid genomen worden indien coherentie bestaat tussen het zogenoemde 'verhaal' of 'scenario' en één van de twee beslisalternatieven (in dit geval: veroordelen versus vrijspreken). Beslissers construeren een coherent scenario door de bekende feiten en bewijsmiddelen in een voor hen logisch en kloppend verhaal te plaatsen. Een scenario wordt beschouwd als coherent indien dit past bij de beschikbare bewijsmiddelen en consistent en compleet is. ${ }^{15}$ De mate waarin het verhaal past bij de beslisalternatieven (in dit geval veroordelen of vrijspreken) bepaalt de uiteindelijke beslissing.

In een Nederlandse strafzaak hoeft de rechter echter niet zelf het verhaal te construeren. Dat is al gedaan door de officier van justitie in de vorm van een tenlastelegging. De rechter toetst vervolgens de bewijsmiddelen aan onderdelen van het

10 Tversky \& Kahneman 1974. Volgens de liberation hypothesis (Kalven \& Zeisel 1966) zijn juryleden eerder geneigd om buitenwettelijke factoren, zoals eigen attitudes en overtuigingen, mee te nemen in hun beslissing wanneer sprake is van twijfel over schuld. Zij voelen zich in dergelijke zaken 'vrij' om buitenwettelijke factoren te gebruiken die hen helpen om een beslissing te nemen. In zaken waarbij schuld van de verdachte duidelijker is, zijn zij meer gebonden aan de strikte regels van bewijswaardering.

11 Dubelaar 2014, p. 29. De Keijser 2017.

12 Tversky \& Kahneman 1974. Epstein 1994. Gunnell \& Ceci 2010.

13 In de literatuur bestaan verschillende theorieën over bewijswaardering die grofweg in te delen zijn in een atomische en een holistische benadering. Bij een atomistische benadering wordt elk bewijsmiddel op zichzelf beoordeeld en gewogen. Bij een holistische benadering ligt de nadruk op de onderlinge samenhang van de bewijsmiddelen en de bewijsconstructie als geheel (zie een overzicht in Dubelaar 2014, p. 38-46).

14 Pennington \& Hastie 1992. Pennington \& Hastie 1993.

15 Hastie 1993. Pennington \& Hastie 1992. 
verhaal door deze te verankeren in algemeen aanvaarde kennis. ${ }^{16}$ Deze werkwijze kan denkfouten zoals confirmation bias in de hand werken: het verhaal van de tenlastelegging is immers het schuldige verhaal. Bij confirmation bias wordt actief gezocht naar informatie of vindt herinterpretatie van informatie plaats om een bestaande overtuiging, verwachting of hypothese te bevestigen. ${ }^{17}$ Dergelijke bias tijdens de rechtszitting kan al zijn ontstaan tijdens het gedragskundig onderzoek. Crombag en collega's wijzen erop dat gedragskundigen op basis van de processtukken, de vraagstelling en informatie die zij aangeleverd krijgen ten behoeve van het onderzoek pro Justitia uitgenodigd worden om uit te gaan van een scenario waarbij de verdachte schuldig is, zelfs als hij ${ }^{18}$ ontkent. ${ }^{19}$ Wanneer psychische problemen worden geconstateerd bij een verdachte, dan kunnen deze als verklaring voor het ten laste gelegde delict dienen. ${ }^{20}$ Op deze manier valt de gedragskundige ten prooi aan confirmation bias die vervolgens tijdens het onderzoek ter terechtzitting doorwerkt. ${ }^{21}$

Naast confirmation bias kunnen andere denkfouten ertoe leiden dat kennis over een stoornis bij een verdachte een schuldig scenario plausibeler maakt. ${ }^{22}$ Volgens de representativiteitsheuristiek kunnen beslissers zich onbewust laten leiden door stereotypen om tot een oordeel te komen. ${ }^{23}$ Een voorbeeld van een dergelijk stereotype is dat een substantieel aandeel van gedetineerden te maken heeft met psychische problemen. De prevalentie van psychische stoornissen onder gedetineerden is ook aanzienlijk hoger dan in de algemene bevolking, ${ }^{24}$ maar dit zegt nog niet direct iets over de prevalentie in een specifieke individuele casus. Daarnaast bestaat de perceptie dat personen met psychische problematiek gevaarlijker zijn dan anderen en worden verschillende psychische stoornissen in verband gebracht met crimineel gedrag. ${ }^{25}$ Dergelijke percepties kunnen ervoor zorgen dat de aanwezigheid van een psychische stoornis in een individuele zaak als schakel of anker kan dienen, waarbij de stoornis (wellicht onterecht) als verklaring voor de ten laste gelegde gedraging wordt gezien en op deze wijze de overtuiging van de rechter beïnvloedt. ${ }^{26}$

\section{Coherence-based reasoning}

De mogelijke invloed van buitenwettelijke factoren, zoals informatie in een PJrapportage, kan ook via psychologische modellen van besluitvorming worden verklaard. Een dergelijk model vanuit de cognitieve psychologie is het model van

Crombag, Van Koppen \& Wagenaar 2005.

Nickerson 1998.

De auteurs zijn zich ervan bewust dat verdachten uiteraard ook vrouwen kunnen zijn.

Crombag, Van Koppen \& Wagenaar 2005.

De Ruiter 2010.

Van Koppen 2004.

Crombag, Van Koppen \& Wagenaar 2005.

Kahneman \& Tversky 1972.

Fazel \& Danesh 2002.

Angermeyer \& Dietrich 2006. Fazel e.a. 2009. Newhill, Eack \& Mulvey 2009.

Tversky \& Kahneman 1974. 


\section{Figuur 1 Het story model}
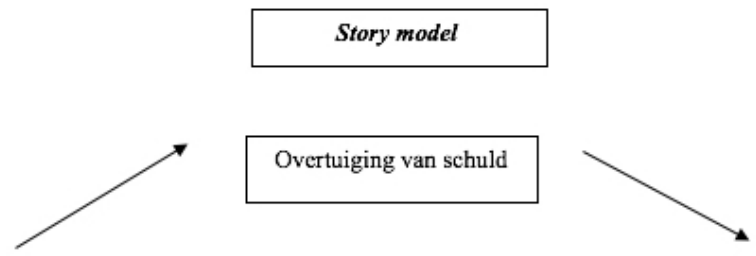

pro Justitia-rapportage

Bewijsbeslissing

coherence-based reasoning (zie figuur 2). ${ }^{27}$ Waar het bij het story model vooral gaat om het toetsen van verschillende scenario's aan de hand van de bewijsmiddelen, is de focus van het model van coherence-based reasoning hoe de gepercipieerde bewijswaarde van losse bewijsmiddelen beïnvloed wordt door de context waarin deze worden gepresenteerd. Het kennisnemen van de verschillende bewijsmiddelen leidt tot cognitieve verschuivingen richting één van beide beslisalternatieven (veroordelen of vrijspreken). De rechter kan de informatie in de PJ-rapportage als contextuele informatie gebruiken die (onbewust) de interpretatie en waardering van de verschillende bewijsmiddelen kan beïnvloeden: ${ }^{28}$ een bewijsmiddel dat niet direct wijst op schuld kan wel als sterker worden geïnterpreteerd, doordat de context waartegen het geïnterpreteerd wordt, het onderzoek pro Justitia, ${ }^{29}$ richting schuld wijst. Een versterkend effect kan dan ook optreden bij bewijsmiddelen die al op schuld wijzen. Deze relatie kan in beide richtingen werken: de bewijswaarde van de bewijsmiddelen bepaalt de conclusie, maar de bewijswaarde van de bewijsmiddelen wordt evengoed bepaald door de mate waarin ze bij de conclusie passen. ${ }^{30}$

\section{Eerder onderzoek}

In het verleden is veelvuldig (internationaal) onderzoek gedaan naar de mogelijke ongewenste invloed van kenmerken van de persoon van de verdachte op beslissingen over schuld ${ }^{31}$ en straf. ${ }^{32}$ Onderzoek naar deze factoren richtte zich onder andere op kenmerken van de verdachte zoals etniciteit, geslacht, sociaal-economi-

29 Crombag, Van Koppen \& Wagenaar 2005.Van Koppen 2004.

30 Simon 2004.

31 Zie bijvoorbeeld deze meta-analyse door Devine \& Caughlin 2014. Zie De Keijser \& Van Koppen 2004 voor een Nederlandse studie.

32 Zie bijvoorbeeld deze review door Goodman-Delahunty \& Sporer 2010. Zie De Keijser \& Van Koppen 2004 voor een Nederlandse studie. 
Figuur 2 Het model van coherence-based reasoning

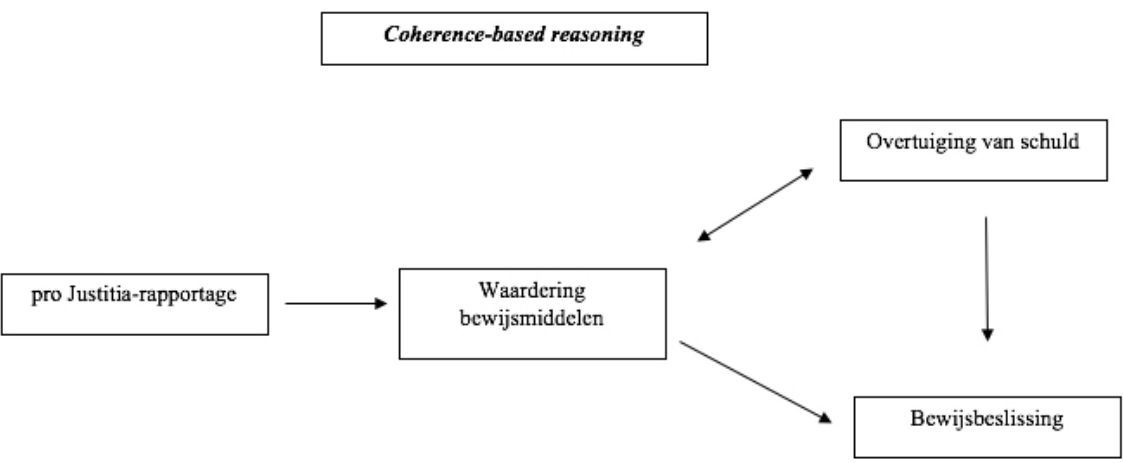

sche status en fysieke aantrekkelijkheid van de verdachte. ${ }^{33}$ Uit verschillende overzichtsstudies bleek dat dergelijke kenmerken een rol spelen bij beslissingen over schuld en straf, al werden niet voor elk kenmerk (bijv. etniciteit) consistente resultaten gevonden. ${ }^{34}$

Onderzoek naar een mogelijk ongewenste rol van een psychische stoornis bij een verdachte in de bewijsbeslissing is echter schaars en is met name in accusatoire rechtssystemen uitgevoerd. ${ }^{35}$ Zo wordt in de Angelsaksische literatuur gerapporteerd over een aantal onderzoeken naar de effecten van informatie over een stoornis bij de verdachte op de uiteindelijke bewijsbeslissing. Mossière en Maeder hebben experimenteel onderzoek in Canada uitgevoerd bij twee groepen, namelijk een steekproef van studenten $(\mathrm{N}=105)$ en een steekproef uit de algemene bevolking ( $\mathrm{N}=140)$, naar de effecten van verschillende typen stoornissen (depressie, obsessieve-compulsieve stoornis, schizofrenie en middelenmisbruik) op de bewijsbeslissing. ${ }^{36}$ De keuze voor die stoornissen werd gemaakt om een vergelijking te kunnen maken tussen stoornissen die geassocieerd worden met agressie (namelijk schizofrenie en middelenmisbruik) en stoornissen waarbij die associatie minder wordt gemaakt (namelijk obsessieve-compulsieve stoornis en depressie). De informatie over de stoornis werd aangeboden als onderdeel van het alibi van de verdachte en niet direct door een gedragskundige in het strafproces. Uit de resultaten kwam geen direct significant effect van enige stoornis op de bewezenverklaring van het delict naar voren. Wel vonden ze via een padmodel dat de twee groepen deze informatie op een andere manier verwerkten om tot hun beslissing te komen. Deze relaties waren echter enkel randsignificant $(p<0,10)$. Bij studenten droeg de aanwezigheid van enige stoornis enkel bij aan de bewijsbeslissing wanneer gevraagd werd hoe zeker zij waren over de bewijsbeslissing. In de

33 Zie onder andere een meta-analyse door Mazzella \& Feingold 1994. Zie ook onderzoek in de Nederlandse context naar het effect van sekse (Bijleveld \& Elffers 2010) en etniciteit (zie voor een overzicht Wermink e.a. 2010) op straftoemeting.

34 Vergelijk Mazzella \& Feingold 1994 en Mitchell e.a. 2005.

35 Zie een recente review naar de effecten van gedragskundige informatie op verschillende beslissingen in het strafrecht (Van Es, Kunst \& De Keijser 2020).

Mossière \& Maeder 2015. 
steekproef uit de algemene bevolking was geen sprake van een dergelijke relatie en droeg een psychische stoornis bij de verdachte enkel marginaal $(p<0,10)$ en negatief bij aan de invloed van de (fysieke) bewijsmiddelen op de bewijsbeslissing. Dit resultaat laat zien dat in hoeverre en de manier waarop informatie over de psychische gesteldheid van een verdachte doorwerkt, verschilt per type beslisser. Het type stoornis maakte daarbij geen verschil.

Mowle en collega's voerden een experiment uit onder 419 personen die opgeroepen waren om in een jury plaats te nemen in de Verenigde Staten. ${ }^{37} \mathrm{Zij}$ onderzochten onder andere het effect van een getuigenverklaring door een psycholoog over de stoornis psychopathie versus schizofrenie op de bewijsbeslissing. Daarnaast is in dit onderzoek gekeken naar de rol van politieke voorkeur (conservatief of liberaal) van het jurylid in dit effect. De onderzoekers lieten zien dat psychopathie een direct effect had op de bewijsbeslissing; indien informatie over de aanwezigheid van psychopathie bij de verdachte werd gegeven, werd deze vaker schuldig bevonden. In het geval van schizofrenie was er sprake van een negatief interactieeffect op de bewijsbeslissing voor meer liberale juryleden. Dat wil zeggen dat informatie over de aanwezigheid van schizofrenie ertoe leidde dat de verdachte minder vaak schuldig werd bevonden, maar enkel door meer liberaal politiek georiënteerde juryleden. Deze studie laat dus zien dat de invloed van een stoornis op de bewijsbeslissing wel degelijk kan verschillen per type stoornis.

Dat er weinig bekend is over de rol van een psychische stoornis in de bewijsbeslissing kan overigens verklaard worden doordat in bepaalde jurisdicties, waaronder de Verenigde Staten en Engeland, het strafproces opgesplitst is in twee fasen: een bewijsfase en een straftoemetingsfase. Op deze manier wordt getracht de mogelijke ongewenste invloed van persoonsinformatie over de verdachte, zoals een strafblad en psychische problemen, te beperken. In een eerste fase wordt dan door een jury beslist over schuld van de verdachte. Vervolgens kan aanvullende informatie die relevant is voor de straftoemeting worden verstrekt voordat de rechter beslist over de straf. ${ }^{38}$ In het Nederlandse strafproces worden beslissingen over bewijs en straf in dezelfde zitting genomen en is de kans aanwezig dat informatie die relevant is voor de straftoemeting, maar onwenselijk is voor de bewijsbeslissing, een rol speelt bij de bewijsbeslissing. Dat maakt onderzoek in de Nederlandse context des te belangrijker. Toch is de onderzoeksleemte in dit geval nog groter. De studies die zijn uitgevoerd in Nederland lijken uit te wijzen dat informatie uit een PJ-rapportage wel degelijk meeweegt in de bewijsbeslissing. Zo tonen uitkomsten van onderzoek bestaande uit interviews met rechters, officieren van justitie en advocaten over het tweefasenproces aan, dat zij vermoeden en verwachten dat informatie die relevant is voor de sanctieoplegging (zoals een PJ-rapportage) van invloed kan zijn op de bewijsbeslissing. ${ }^{39}$

In Nederland is, voor zover ons bekend, slechts één experimenteel onderzoek uitgevoerd naar het ongewenste effect van informatie over een stoornis op de bewijsbeslissing. Rassin voerde een experiment uit naar het model van coherence- 
based reasoning ${ }^{40}$ onder 53 Nederlandse rechters, waarbij het effect van een antisociale persoonlijkheidsstoornis en psychopathie, zoals vastgesteld door een psychiater, op de waardering van de overige bewijsmiddelen (vingerspoor) en overtuiging van de rechter in de bewijsbeslissing werd onderzocht. ${ }^{41}$ In de zaak in een kort vignet was sprake van een ontkennende verdachte en overige bewijsmiddelen die niet direct tot overtuiging van schuld hoefden te leiden. De manipulatie in twee condities bestond uit de aan- of afwezigheid van een diagnose van een antisociale persoonlijkheidsstoornis en psychopathie. Uit de resultaten kwam naar voren dat zowel de waardering van de overige bewijsmiddelen als de overtuiging van de rechter significant hoger was (op een schaal van 1 tot 100) in het geval van de aanwezigheid van een antisociale persoonlijkheidsstoornis en psychopathie. Dit resulteerde vervolgens in een significante verhoging van het percentage positieve bewijsbeslissingen met 33\%. ${ }^{42}$ Eerder Nederlands onderzoek vond aanwijzingen dat professionele rechters minder vatbaar zijn voor denkfouten en bias dan leken. ${ }^{43}$ Wanneer het echter gaat om informatie die relevant is in een zaak voor andere beslissingen dan de bewijsbeslissing, zoals een PJ-rapportage, lijken professionele rechters deze informatie wel mee te wegen in de bewijsbeslissing. ${ }^{44}$ Samengevat kan worden gesteld dat empirisch onderzoek naar de invloed van informatie over een psychische stoornis bij een verdachte op de bewijsbeslissing tot op heden voornamelijk is uitgevoerd in accusatoire rechtssystemen waar de bewijsbeslissing wordt genomen door een jury. Daarnaast laat het onderzoek geen consistente resultaten zien en is vanwege de verschillende rechtssystemen, typen respondent, typen stoornis en de wijze waarop informatie over de stoornis aangeboden werd in de zaak niet direct te generaliseren naar de Nederlandse context. ${ }^{45}$ Toch kan voorzichtig geconcludeerd worden dat de aanwezigheid van een antisociale persoonlijkheidsstoornis of psychopathie het aantal positieve bewijsbeslissingen significant verhoogt. Voor andere typen stoornissen zijn geen eenduidige conclusies te trekken.

\section{Deze studie}

In het huidige onderzoek wordt getracht om het schaarse empirische onderzoek in de Nederlandse context aan te vullen door het experiment van Rassin ${ }^{46}$ uit te breiden tot een grotere steekproef en met een ander type stoornis, namelijk borderline persoonlijkheidsstoornis. ${ }^{47}$ Tevens wordt geëxploreerd op welke wijze een

40 Simon 2004.

41 Rassin 2017.

42 In de huidige studie betekent een positieve bewijsbeslissing dat de verdachte in de casus schuldig wordt bevonden.

43 Zie bijv. De Keijser \& Van Koppen 2004. Schillemans \& Giesen 2020.

44 Rassin 2017.

45 Mossière \& Maeder 2015. Mowle e.a. 2016.

46 Rassin 2017.

47 De verdachte in de casus in het vignet is een vrouw. De keuze voor een borderline persoonlijkheidsstoornis is gebaseerd op prevalentiecijfers van typen stoornissen in de Nederlandse forensische populatie onder vrouwen, zie Muller \& Kempes 2016. 
PJ-rapportage van invloed is op de bewijsbeslissing door het model van coherencebased reasoning en de assimilatie van de waardering van bewijsmiddelen zoals gehanteerd in de studie van Rassin ${ }^{48}$ af te zetten tegen het story model van bewijswaardering. Enerzijds trachten we het onderzoek van Rassin (deels) te repliceren en anderzijds proberen we dit te verdiepen door mogelijke effecten nader te duiden aan de hand van de twee theoretische modellen.

Naast de aan- of afwezigheid van een stoornis, is getoetst of een verschil bestaat tussen de aan- of afwezigheid van een PJ-rapportage. Tijdens de opsporing en vervolging ontstaat een selectie-effect van typen zaken en verdachten waarbij een gedragskundig onderzoek gewenst en geboden is. ${ }^{49}$ Het feit dat een verdachte gedragskundig wordt onderzocht, impliceert dat een vermoeden bestaat dat de verdachte een psychische stoornis heeft, ondanks dat deze wellicht door de gedragskundigen uiteindelijk niet wordt vastgesteld. Om na te gaan in hoeverre een mogelijke perceptie van de aanwezigheid van een stoornis doordat gedragskundig onderzoek is uitgevoerd een rol speelt in de overtuiging, is in de huidige studie ook nagegaan of louter de aanwezigheid van een PJ-rapportage maar zonder een diagnose van een stoornis leidt tot meer positieve bewijsbeslissingen. Op deze manier kan worden gecontroleerd of enkel de aanwezigheid van expertise van gedragskundigen al een mogelijk effect heeft. Dit is in eerder Nederlands onderzoek nog niet getoetst. De onderzoeksvragen die in deze studie centraal staan zijn:

1 In hoeverre hebben de aanwezigheid van een PJ-rapportage en informatie over een psychische stoornis effect op de bewijsbeslissing?

2 Indien een effect wordt gevonden: op welke wijze hebben de aanwezigheid van een PJ-rapportage en de informatie over een psychische stoornis effect op de bewijsbeslissing?

Aan de hand van deze onderzoeksvragen, de besproken modellen en eerder onderzoek kunnen de volgende hypothesen worden opgesteld:

Hypothese 1: Allereerst wordt verwacht dat de aanwezigheid van een PJ-rapportage leidt tot meer positieve bewijsbeslissingen.

Hypothese 2: Tevens wordt verwacht dat het aantal positieve bewijsbeslissingen hoger is indien sprake is van een stoornis in de PJ-rapportage dan wanneer dit niet het geval is.

Aan de hand van de besproken modellen, het story model en het model van coherence-based reasoning, kunnen verschillende hypothesen worden opgesteld die het mogelijke effect van de PJ-rapportage op de bewijsbeslissing nader kunnen duiden:

Hypothese 3: Vanuit het story model wordt verwacht dat de (informatie in de) PJrapportage leidt tot meer overtuiging van schuld en op deze manier tot meer positieve bewijsbeslissingen. 
Hypothese 4: Op basis van het model van coherence-based reasoning wordt verwacht dat de (informatie in de) PJ-rapportage leidt tot een hogere waardering van de bewijsmiddelen in een zaak. Dat leidt vervolgens tot meer overtuiging van schuld en dus meer positieve bewijsbeslissingen.

Beide modellen zullen dus worden getoetst om na te gaan of, en zo ja, voor welk model steun gevonden wordt.

Aan de hand van een experimentele onderzoeksopzet waarin gebruik wordt gemaakt van korte casusbeschrijvingen (vignetten) en verkorte PJ-rapportages is getracht de verschillende hypothesen te toetsen en de onderzoeksvraag te beantwoorden. Hierna volgt een beschrijving van de methode en worden de resultaten met betrekking tot de verschillende hypotheses gerapporteerd. Tot slot wordt in de discussie ingegaan op de betekenis van deze resultaten voor toekomstig onderzoek en de rechtspraktijk.

\section{Methode}

\section{Participanten}

Aan het huidige experiment namen 155 bachelor criminologiestudenten van de Universiteit Leiden deel. ${ }^{50}$ De steekproef bestond voor $92,9 \%$ uit vrouwen ${ }^{51}$ met een gemiddelde leeftijd van 20,23 jaar ( $S D=1,99)$. Meer dan de helft van de participanten $(54,8 \%)$ was eerstejaars criminologiestudent, de overige participanten waren ouderejaars criminologiestudent. ${ }^{52}$ Participanten zijn in één week geworven tijdens een van hun werkcolleges en gevraagd om vrijwillig deel te nemen aan de huidige studie. Zij zijn willekeurig toegewezen aan een van de drie mogelijke condities. Zij waren niet op de hoogte van het daadwerkelijke doel van het onder-

50 In het bestaande internationale onderzoek naar de mogelijke invloed van informatie over psychische stoornissen op rechterlijke beslissingen worden veelal psychologiestudenten of participanten uit de algemene bevolking gebruikt (zie Van Es, Kunst \& De Keijser 2020; Mossière \& Maeder 2015; Mowle e.a. 2016). Deze respondenten hebben vaak weinig tot geen kennis van het strafproces. Psychologiestudenten hebben daarnaast meer kennis over psychopathologie dan een gemiddelde jurist, waardoor attitudes ten aanzien van verdachten met een psychische stoornis anders kunnen zijn (Mossière \& Maeder 2015). Criminologiestudenten hebben in hun bacheloropleiding in principe evenveel onderwijs in het strafrecht als bachelorstudenten rechtsgeleerdheid en verwacht mag worden dat zij representatiever zijn voor juridische professionals dan studenten van andere studierichtingen. In de periode van de dataverzameling van het onderhavige onderzoek was het mogelijk om een grote groep criminologiestudenten te benaderen via de werkcolleges van een vak. Om deze praktische reden is ervoor gekozen om enkel criminologiestudenten te werven. Uiteraard blijft het een steekproef van studenten die niet direct representatief is voor juridische professionals in Nederland. Dit heeft gevolgen voor de externe validiteit van de resultaten (Van der Laan, Van Busschbach \& Bijleveld 2007).

51 Het gegeven dat de steekproef uit vrijwel alleen maar vrouwen bestaat, kan worden verklaard door de man/vrouw-verdeling binnen de opleiding criminologie aan de Universiteit Leiden. Het overgrote deel van de criminologiestudenten is vrouw.

52 De resultaten verschilden niet significant tussen eerstejaars- en ouderejaarsstudenten. Er bestond daarnaast geen significant verschil tussen de verschillende condities wat betreft leeftijd en sekse. 
zoek. Zij konden de vragenlijst in stilte en zonder overleg op papier invullen tijdens de pauze in het college (gemiddeld tien minuten).

\section{Instrumentarium}

\section{Vignet}

Alle participanten kregen een korte beschrijving van een fictieve zaak (gebaseerd op experimenten door Ask \& Granhag, en Rassin), ${ }^{53}$ waarin een levensdelict op een huisarts werd beschreven:

Een man wordt dood aangetroffen in een appartement. Hij is door een misdrijf om het leven gekomen. Een vrouw, Eva, wordt ook aangetroffen in het appartement en wordt aangehouden als de verdachte in de zaak. Het slachtoffer is een huisarts en het appartement is zijn kantoor. Het slachtoffer en Eva kenden elkaar, aangezien Eva patiënt was in de huisartsenpraktijk. Zij bleken ook een geheime affaire te hebben. Het slachtoffer werd om het leven gebracht met een mes. De verdachte werd door de politie aangetroffen op de plaats delict met bloedvlekken op haar kleding. Enkel haar vingerafdrukken werden aangetroffen op het mes. De verdachte ontkent echter iedere betrokkenheid bij het misdrijf en verklaart dat een onbekende mannelijke indringer het slachtoffer aanviel met het mes. De man droeg handschoenen. Zij heeft geprobeerd de aanvaller te stoppen door het mes af te pakken en zegt dat ze op dat moment gewond is geraakt. De aanvaller zou haar omver hebben geduwd en vervolgens zijn gevlucht. De huisartsassistente heeft verklaard dat zij op de hoogte was van de geheime affaire tussen het slachtoffer en de verdachte en dat het slachtoffer haar in vertrouwen had verteld dat hij van plan was de relatie te beëindigen. Ten slotte verklaarde een overbuurman dat hij rond het tijdstip van het misdrijf op straat een man zag rennen vlakbij het huis van het slachtoffer. Deze buurman kon zich niet herinneren of de man handschoenen aan had of niet. De verdachte wordt uiteindelijk vervolgd voor doodslag.

Omdat de overtuiging van de beslisser hier centraal staat, was de zaak op een dusdanige manier opgesteld dat er voldoende wettig bewijs was, maar dat naar het oordeel van de onderzoekers ruimte was voor twijfel met betrekking tot de overtuiging van daderschap. De casus is grotendeels gebaseerd op het aangehaalde onderzoek van Rassin, wat een indicatie gaf dat deze twijfel aanwezig was. ${ }^{54}$ Het werd pas duidelijk bij de uitvoer of deze twijfel ook daadwerkelijk voldoende aanwezig was. 


\section{Manipulatie}

De experimentele manipulatie bestond uit het variëren van de aanwezigheid van een PJ-rapportage en de inhoud daarvan. Dit resulteerde in een 2 (PJ-rapportage: aanwezig vs. afwezig) x 2 (Stoornis: afwezig vs. borderline persoonlijkheidsstoornis) incompleet factor design (between-subjects), waarbij de participanten willekeurig aan een conditie werden toegewezen. ${ }^{55}$ Het onderzoeksontwerp is weergegeven in figuur 3 .

Aangezien het in dit experiment ging om de bewijsbeslissing en het een ontkennende verdachte betrof, is enkel de vaststelling van een stoornis door een psycholoog en psychiater gegeven. Er is geen uitspraak gedaan over een mogelijke relatie tussen de stoornis en het delict, het recidiverisico of gegeven adviezen over toerekeningsvatbaarheid en maatregelen. ${ }^{56}$ In deze casus is gekozen voor een borderline persoonlijkheidsstoornis. Deze keuze is gebaseerd op prevalentiecijfers van typen stoornissen in de forensische populatie onder vrouwen. ${ }^{57}$ Hierbij zijn ook de symptomen voor de stoornis benoemd (onder andere afhankelijkheid in relaties, gebrek aan inzicht in intimiteit en relaties, emotieregulatie en impulsiviteit ${ }^{58}$ ) om te voorkomen dat participanten een eigen invulling aan het ziektebeeld van de stoornis zouden geven wanneer enkel de stoornis zou zijn benoemd. In de conditie waarin wel een PJ-rapportage aanwezig was maar geen stoornis werd vastgesteld, zijn verder ook geen symptomen van een mogelijke stoornis gegeven.

\section{Uitkomstmaten}

$\mathrm{Na}$ het lezen van de beschrijving van de zaak, dienden de participanten een korte vragenlijst in te vullen. Allereerst werden demografische gegevens uitgevraagd (geslacht, leeftijd, studie en studiejaar). Vervolgens werd hun verzocht een oordeel te geven over (zie ook figuur 3):

55 Het toevoegen van een manipulatiecheck over de aanwezige PJ-rapportage en stoornis was in dit onderzoek niet doeltreffend, aangezien het experiment op papier werd ingevuld. Dit gaf de participanten de mogelijkheid om terug te bladeren naar de casus om informatie voor de manipulatiechecks op te zoeken. Om deze reden is geen manipulatiecheck toegevoegd.

56 Wij zijn ons ervan bewust dat een volledig PJ-rapport deze informatie wel bevat. Om een uniek effect van de aanwezigheid van een stoornis te kunnen toetsen is ervoor gekozen om enkel de diagnose van een stoornis weer te geven. Hierbij is tevens aangesloten bij de Richtlijn psychiatrisch onderzoek en rapportage in strafzaken (Nederlandse Vereniging voor Psychiatrie 2013), waarin wordt aanbevolen om niet te rapporteren over een relatie tussen een eventuele gebrekkige ontwikkeling of ziekelijke stoornis en het ten laste gelegde, omdat het ontbreekt aan inzicht in motivatie en beweegredenen. Hierdoor wordt het onmogelijk om deze relatie te leggen. Het gebruik van vignetten maakt het mogelijk om complexe vraagstukken, zoals de bewijsbeslissing, op een overzichtelijke wijze te onderzoeken met zo min mogelijk storende factoren (Hughes \& Huby 2004). Door het manipuleren van variabelen en het willekeurig toewijzen van respondenten aan verschillende condities, is de interne validiteit van het onderzoek hoog. Een dergelijk gecontroleerd onderzoek gaat echter meestal gepaard met vereenvoudiging van het materiaal (in casu een beknopt vignet) en een onderzoekssetting die niet direct correspondeert met de praktijk (in casu tijdens het onderwijs). Deze keuzes hebben gevolgen voor de externe en, met name, ecologische validiteit van het onderzoek (Atzmüller \& Steiner 2010; Sniderman \& Grob 1996).

57 Muller \& Kempes 2016.

58 American Psychiatric Association 2013. 
1 waardering van het vingerspoor als bewijsmiddel op een schaal ( 1 = totaal niet sterk, 10 = heel erg sterk);

2 overtuiging van schuld op een schaal ( 1 = niet overtuigd, 10 = zeer overtuigd);

3 bewijsbeslissing (op basis van het bewijs en uw overtuiging, denkt $u$ dat de verdachte het ten laste gelegde feit heeft begaan? (nee/ja)).

\section{Figur 3 Visuele representatie van het onderzoeksontwerp}

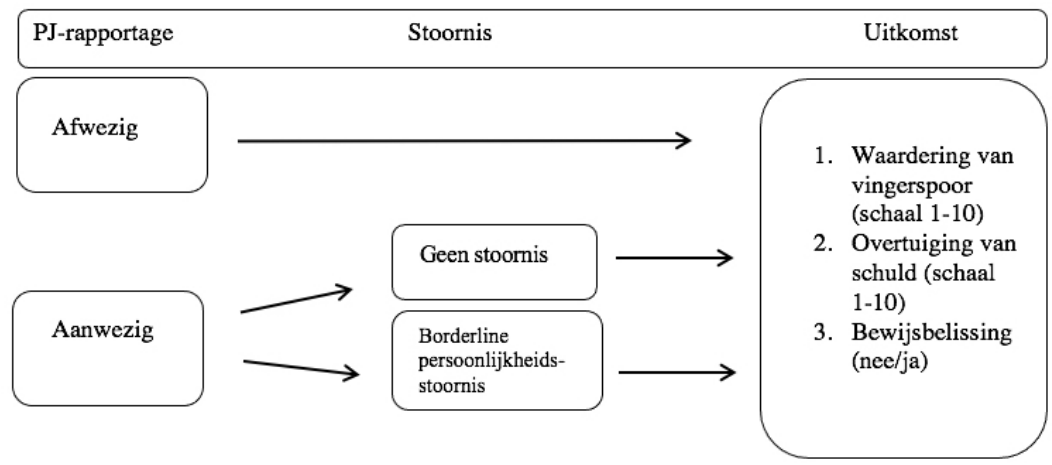

\section{Analyses}

Een chikwadraattoets (inclusief bijbehorende post hoc-analyses aan de hand van aangepaste, gestandaardiseerde residuen) is uitgevoerd om het verschil in percentage positieve bewijsbeslissingen tussen de condities te toetsen. Om de verschillen tussen de condities met betrekking tot de waardering van het vingerspoor en de overtuiging van schuld te toetsen, zijn variantieanalyses (ANOVA) uitgevoerd met bijbehorende Bonferroni post hoc-toetsen. ${ }^{59}$ Ten slotte zijn mediatieanalyses uitgevoerd met behulp van de PROCESS-macro in SPSS. ${ }^{60}$ Op deze manier is via (logistische) regressiemodellen onderzocht via welk pad de bewijsbeslissing tot stand is gekomen.

\section{Resultaten}

Figuur 4 laat de percentages positieve bewijsbeslissingen zien voor de participanten die geen PJ-rapportage hadden gekregen $(42,3 \%, n=22)$, de participanten die een PJ-rapportage zonder gediagnostiseerde stoornis kregen $(54 \%, n=27)$ en de

59 De schaalvariabelen over de waardering van het vingerspoor en de overtuiging van schuld waren niet normaal verdeeld. Gesteld wordt dat de ANOVA-toets vrij robuust is tegen schending van de normaliteitsassumptie (Blanca e.a. 2017). Bonferroni post-hoc tests zijn uitgevoerd om te corrigeren voor mogelijke kanskapitalisatie (Field 2018). Vanwege de schending van de normaliteitsassumptie zijn ook de non-parametrische Kruskall-Wallis tests uitgevoerd op basis van rangscores. Post-hoc analyses zijn gedaan door middel van pairwise comparisons om te corrigeren voor mogelijke kanskapitalisatie. Uit deze tests kwamen dezelfde resultaten naar voren. 
Figuur 4 Percentage positieve bewijsbeslissingen per conditie

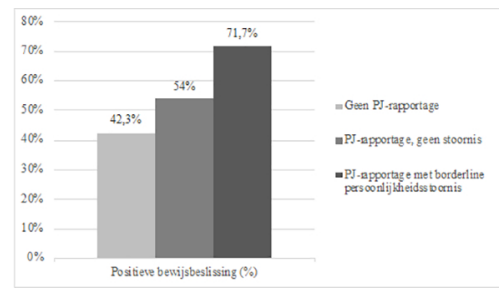

participanten die een PJ-rapportage met een borderline persoonlijkheidsstoornis hadden $(71,7 \%, n=38)$. In geen van de condities was het aantal positieve bewijsbeslissingen $100 \%$, hetgeen indiceert dat de casus in het vignet, zoals bedoeld, ruimte voor twijfel liet. Indien een PJ-rapportage aanwezig was in de zaak, steeg het percentage van positieve bewijsbeslissingen (zie figuur 4). Het verschil in positieve bewijsbeslissingen was echter enkel significant wanneer de controleconditie zonder PJ-rapportage werd vergeleken met de conditie waarin een borderline persoonlijkheidsstoornis was gediagnosticeerd bij de verdachte. ${ }^{61}$ Vergelijkbaar met de studie van Rassin was dit een toename van bijna $30 \%$. Het effect is van gemiddelde grootte (Cramer's $V=0,246$ ).

De aanwezigheid van een borderline persoonlijkheidsstoornis in een PJ-rapportage bleek eveneens van invloed te zijn op de overtuiging van schuld (zie figuur 5). ${ }^{62}$ De gemiddelde overtuiging van schuld was significant hoger $(M=$ $6,60, S D=1,34$ ) indien een borderline persoonlijkheidsstoornis was gediagnosticeerd dan wanneer wel een rapportage aanwezig was, maar geen stoornis kon worden vastgesteld $(M=5,88, S D=1,61, p=0,046)$ en wanneer geen PJ-rapportage aanwezig was $(M=5,83, S D=1,53, p=0,025)$. Deze laatste twee condities verschilden voor wat betreft de overtuiging van schuld niet significant van elkaar $(p=1,000)$. Aangezien de overtuiging van schuld gemiddeld tot sterk samenhangt met de uiteindelijke bewijsbeslissing in elke conditie, ${ }^{63}$ kan worden gesteld dat indien de overtuiging van schuld op een schaal van 1 tot 10 hoger is dan 6 , dat tot significant meer positieve bewijsbeslissingen leidt. De gemiddelde waardering van het vingerspoor als bewijsmiddel verschilde niet significant tussen de condities (zie figuur 5). ${ }^{64}$

Om na te gaan op welke wijze de bewijsbeslissing tot stand is gekomen, is de bewijsbeslissing voorspeld door middel van mediatiemodellen gebaseerd op het story model en het model van coherence-based reasoning. ${ }^{65}$ Omdat enkel de conditie met een PJ-rapportage met de diagnose van een borderline persoonlijkheidsstoornis een significant verschil in positieve bewijsbeslissingen liet zien, is naar de voorspellende waarde van deze conditie in de modellen gekeken. De waarde-

$61 \chi^{2}(2)=9.343, p=0,009$.

$62 F(2,152)=4,325, p=0,015, \eta^{2}=0,05$.

63 Spearman's $r s=0,64-0,80, p<0,001$.

$64 F(2,152)=0,915, p=0,403$.

65 Pennington \& Hastie 1992. Pennington \& Hastie 1993. Simon 2004. 
Figuur 5 Overtuiging van schuld en waardering van vingerspoor

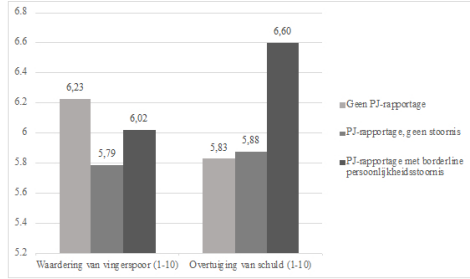

Figuur 6 Mediatiemodel PJ-rapportage, overtuiging van schuld en bewijsbeslissing
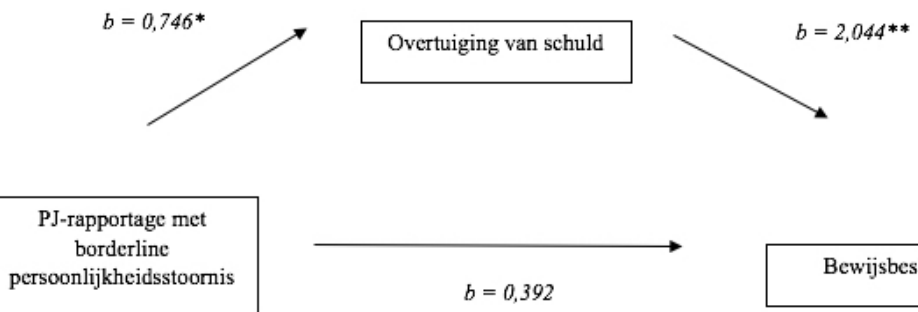

Bewijsbeslissing

Noot: Mediatiemodel: $\chi^{2}(2)=15,33, p<0,001\left({ }^{*} p<0,01,{ }^{* *} p<0,001\right)$. Indirect effect van de PJrapportage op de bewijsbeslissing via overtuiging van schuld is $b=1,52,95 \% \mathrm{BCa} C \mathrm{CI}[0,56 ; 2,92], \mathrm{R}^{2}=$ 0,6976 (Nagelkerke).

ring van het vingerspoor en de overtuiging van schuld dienden als mediatoren in deze modellen.

\section{Story model}

Uit de analyses kwam naar voren dat de overtuiging van schuld een mediator bleek voor het effect van de aanwezigheid van een PJ-rapportage met informatie over de borderline persoonlijkheidsstoornis bij de verdachte en de bewijsbeslissing (zie figuur 6). Het effect van de PJ-rapportage op de uiteindelijke bewijsbeslissing wordt dus verklaard doordat de overtuiging van schuld toeneemt.

\section{Coherence-based reasoning}

De waardering van het vingerspoor als bewijsmiddel bleek geen mediator van het effect van een PJ-rapportage en de bewijsbeslissing te zijn. Er was geen relatie tussen de aanwezigheid van een PJ-rapportage met een diagnose van borderline persoonlijkheidsstoornis en de waardering van het vingerspoor als bewijsmiddel ( $b=0,004, p=0,988)$. Hoewel de waardering van het vingerspoor wel significant gecorreleerd is aan de bewijsbeslissing, ${ }^{66}$ bleek uit aanvullende analyses dat dit 


\section{Figuur 7 Mediatiemodel PJ-rapportage, waardering van bewijsmiddelen en} bewijsbeslissing

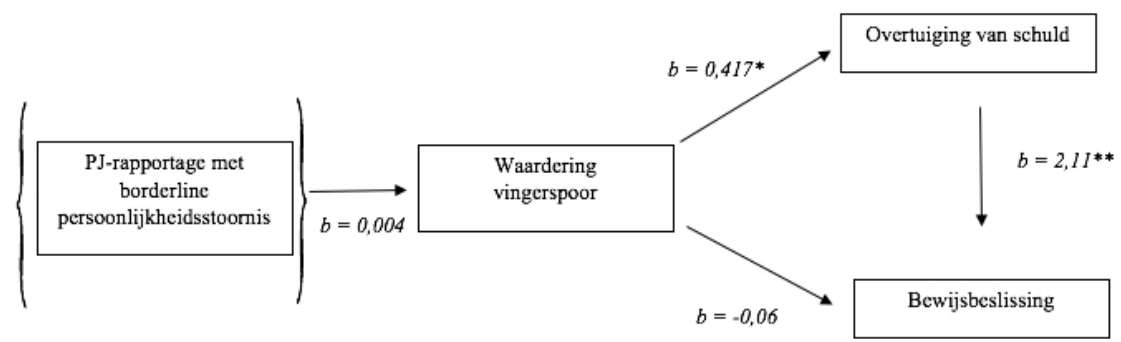

Noot: Mediatiemodel: $\chi^{2}(2)=14,53, p<0,001\left({ }^{*} p<0,01,{ }^{* *} p<0,001\right)$. Indirect effect van de waardering van het vingerspoor op de bewijsbeslissing via overtuiging van schuld is $b=0,879,95 \% \mathrm{BCa} C \mathrm{I}$ $[0,50 ; 1,46], R^{2}=0,6959$ (Nagelkerke).

verband volledig gemedieerd werd door de overtuiging van schuld en onafhankelijk was van de aan- of afwezigheid van een PJ-rapportage (zie figuur 7). ${ }^{67}$

\section{Discussie}

Het doel van de huidige studie was om na te gaan in hoeverre en op welke wijze de aanwezigheid van een PJ-rapportage en informatie over een psychische stoornis bij een verdachte van invloed zijn op de bewijsbeslissing. De verwachting was dat de aanwezigheid van een PJ-rapportage tot meer positieve bewijsbeslissingen zou leiden. Daarnaast werd verwacht dat de aanwezigheid van een stoornis in een PJrapportage zou leiden tot meer positieve bewijsbeslissingen dan wanneer deze afwezig was. Het onderzoek wees uit dat de aanwezigheid van een borderline persoonlijkheidsstoornis een significant positief effect had op de overtuiging van schuld en het percentage positieve bewijsbeslissingen ten opzichte van de controlegroep zonder PJ-rapportage. Vervolgens is getracht om via verschillende modellen van bewijswaardering en besluitvorming dit effect nader te duiden. Vanuit het story model werd verwacht dat de (informatie in de) PJ-rapportage zou leiden tot meer overtuiging van schuld en op deze manier tot meer positieve bewijsbeslissingen zou leiden. Op basis van het model van coherence-based reasoning werd verwacht dat de (informatie in de) PJ-rapportage zou leiden tot een hogere waardering van de overige bewijsmiddelen in een zaak. Dit zou vervolgens leiden tot

67 Aanvullende analyses toonden aan dat sprake is van een significante relatie tussen de overtuiging van schuld en de waardering van het vingerspoor $(b=0,481, p<0,000)$. De relatie tussen overtuiging van schuld en de bewijsbeslissing werd echter niet gemedieerd door de waardering van het vingerspoor $(b=-0,06, p=0,743)$. Deze resultaten verschilden niet tussen de condities met de aanwezigheid of de inhoud van een PJ-rapportage. Dit is een indicatie dat overtuiging van schuld geen effect had op de waardering van de bewijsmiddelen en daarmee de bewijsbeslissing, zoals volgens het coherence-based reasoning (Simon 2004) model zou worden verwacht. 
meer overtuiging van schuld en dus tot meer positieve bewijsbeslissingen. Uit de verdiepende mediatieanalyses bleek de aanwezigheid van een stoornis in een PJrapportage een indirecte voorspeller te zijn van een positieve bewijsbeslissing, namelijk via de overtuiging van schuld. De aanwezigheid van een stoornis in een PJ-rapportage heeft dus direct invloed op hoe overtuigd de beslisser is van de schuld van de verdachte, maar de aanwezigheid of de inhoud van de rapportage heeft geen effect op de waardering van de overige bewijsmiddelen in de zaak.

De resultaten in de huidige studie zijn vergelijkbaar en grotendeels overeenkomstig met het onderzoek van Rassin. ${ }^{68}$ Het percentage positieve bewijsbeslissingen was vergelijkbaar in beide experimenten en ook de relatieve stijging van positieve bewijsbeslissingen was vergelijkbaar (ongeveer 30\%). Het vignet in de huidige studie is ook gebaseerd op het vignet dat gehanteerd is in die specifieke studie, met het belangrijkste verschil dat het effect van een andere stoornis (namelijk borderline persoonlijkheidsstoornis in plaats van antisociale persoonlijkheidsstoornis en psychopathie) is getoetst. Daarbij zijn naast enkel de benoeming van de aanwezigheid van de stoornis ook (gedrags)symptomen van de stoornis gegeven om te voorkomen dat enkel het label van een psychische stoornis een effect zou hebben ${ }^{69}$ en participanten een eigen invulling aan het ziektebeeld zouden geven. De toevoeging van een conditie met een PJ-rapportage zonder diagnose, om te controleren voor een mogelijk effect van enkel de aanwezigheid van expertise van gedragskundigen, resulteerde wel in een verhoging van het percentage positieve bewijsbeslissingen (van $42 \%$ naar 54\%), maar dit was niet significant.

Er lijkt wel steun te zijn gevonden voor het story model waarbij complexe beslissingen in onzekerheid worden genomen aan de hand van de coherentie van een verhaal. ${ }^{70}$ De aanwezigheid van een stoornis heeft ertoe geleid dat de beslisser meer overtuigd was van het schuldige scenario. De psychische stoornis biedt een verklaring voor het ten laste gelegde feit, aangezien de symptomen coherent zijn met het vertoonde gedrag. ${ }^{71}$ Dit leidt tot meer positieve bewijsbeslissingen en een hogere overtuiging van schuld. Anders dan in de studie van Rassin lijkt het effect van een PJ-rapportage op de bewijsbeslissing niet verklaard te worden doordat het de waardering van de overige bewijsmiddelen beïnvloedt. ${ }^{72}$ In onze studie is geen sprake van onderlinge beïnvloeding van bewijs en overige informatie over de zaak, zoals beargumenteerd wordt volgens de idee van coherence-based reasoning. ${ }^{73}$ In aanvulling op de eerdere studie door Rassin ${ }^{74}$ naar de invloed van de aanwezigheid van een stoornis bij de verdachte op de bewijsbeslissing uitgevoerd onder professionele rechters, laat de huidige studie dus zien dat ook leken vatbaar zijn voor bias door informatie over een psychische stoornis in een PJ-rapportage. De manier waarop dat gebeurt, lijkt dus wel te verschillen naar het type beslisser. 


\section{Beperkingen}

In de huidige studie dient een aantal beperkingen in acht te worden genomen. In tegenstelling tot de realiteit, en daarmee ten nadele van de ecologische validiteit, is gebruikgemaakt van een korte beschrijving van een zaak en van informatie in een PJ-rapportage. Het gebruik van deze verkorte beschrijvingen maakt het wel mogelijk complexe vraagstukken, zoals de bewijsbeslissing, op een overzichtelijke wijze te onderzoeken met zo min mogelijk storende factoren. ${ }^{75}$ Enkel de aan- of afwezigheid en de inhoud van de PJ-rapportage is gevarieerd en alle overige aspecten in de casus zijn constant gehouden in de verschillende condities. Daarnaast zijn de participanten willekeurig toegewezen aan een van deze condities, waardoor de gevonden effecten toegeschreven kunnen worden aan de manipulatie. Deze opzet is dan ook bevorderlijk voor de interne validiteit van het onderzoek. Een dergelijk gecontroleerd onderzoek gaat echter meestal gepaard met vereenvoudiging van het materiaal (in casu een beknopt vignet) en een onderzoekssetting die niet direct correspondeert met de praktijk (in casu tijdens het onderwijs). ${ }^{76}$

Ten tweede is het experiment uitgevoerd onder criminologiestudenten. Ondanks dat criminologiestudenten een aantal strafrechtgerelateerde vakken hebben gevolgd en daardoor wellicht representatiever zijn voor juridische professionals dan bijvoorbeeld psychologiestudenten die in eerder internationaal onderzoek werden gebruikt, ${ }^{77}$ zijn dit geen professionele rechters die in Nederland de beslissingen nemen. Dat kan consequenties hebben voor de externe validiteit van de huidige studie. ${ }^{78}$ De resultaten zijn echter wel grotendeels in overeenkomst met het onderzoek van Rassin, dat uitgevoerd is onder professionele rechters. ${ }^{79}$

\section{Aanbevelingen}

Gelet op de bovengenoemde beperkingen en de gevonden resultaten, kan een aantal aanbevelingen worden gedaan voor vervolgonderzoek. Ten eerste is in het huidige onderzoek enkel de aan- en afwezigheid van een PJ-rapportage en één mogelijke stoornis gemanipuleerd. Een PJ-rapportage bevat echter meer informatie dan enkel diagnostische overwegingen. Vervolgonderzoek dient zich ook te richten op mogelijke effecten van andere typen informatie in deze rapportages (bijv. recidiverisico, advies over toerekeningsvatbaarheid indien daar uitspraken over zijn gedaan) op de bewijsbeslissing.

Ten tweede is in Nederland nog geen vergelijkend onderzoek gedaan naar mogelijke effecten van verschillende stoornissen. Eerder internationaal onderzoek liet zien dat verschillende typen stoornissen verschillende effecten kunnen

77 Mowle e.a. 2016. Mossière \& Maeder 2015.

78 Atzmüller \& Steiner 2010. Sniderman \& Grob 1996. Van der Laan, Van Busschbach \& Bijleveld 2007.

Hughes \& Huby 2004

Rassin 2017. 
hebben op de bewijsbeslissing. ${ }^{80}$ Het huidige onderzoek trachtte een ander type stoornis te toetsen dan in eerder onderzoek van Rassin is gedaan. ${ }^{81}$ Er werden vergelijkbare resultaten gevonden. Beide typen stoornissen (antisociale persoonlijkheidsstoornis/psychopathie en borderline persoonlijkheidsstoornis) waren wat betreft symptomatologie echter coherent met het type delict. Beide stoornissen kunnen een verklaring bieden voor gewelddadig gedrag. ${ }^{82}$ Vervolgonderzoek kan zich richten op stoornissen die (veelvuldig en eventueel comorbide) voorkomen in forensische populaties maar wellicht minder congruent zijn met het type delict (bijvoorbeeld een psychotische stoornis bij een seksueel delict). ${ }^{83}$ Daarbij kan mogelijke interactie met type en ernst van het delict (bijv. gewelds- versus vermogensdelicten) ook worden bestudeerd. Wellicht dat in geval van een ernstiger delict, informatie over een mogelijke psychische stoornis een sterker effect heeft dan in een minder ernstige zaak, zoals beargumenteerd volgens de overtuigingsparadox. ${ }^{84}$

Ten derde zouden de resultaten in de huidige studie verklaard kunnen worden door het story model van bewijswaardering. In het experiment werd in elke conditie de informatie in dezelfde volgorde aan de participanten voorgelegd. Om de theorie van het story mode ${ }^{85}$ nauwkeuriger te toetsen, is het voor toekomstig onderzoek van belang om ook te variëren in de volgorde van de presentatie van de bewijsmiddelen. Op deze manier kan worden getoetst of de juridische beslissingen ook daadwerkelijk volgens een verhaalmodel worden genomen of dat wellicht toch ook sprake is van assimilatie van bewijsmiddelen. ${ }^{86}$ Ten slotte is het noodzakelijk om bovenstaande aanbevelingen te toetsen in een grotere steekproef van Nederlandse professionele rechters. Als in een dergelijke replicatiestudie eenzelfde resultaat naar voren komt, zou het voor de praktijk een overweging kunnen zijn om het strafproces in bepaalde zaken waarin een PJ-rapportage en de inhoud mogelijk een onwenselijke invloed kan hebben, op te splitsen in twee fasen: een bewijsfase en een straftoemetingsfase. In een aantal westerse jurisdicties, waaronder de Verenigde Staten en Engeland, wordt dit ook gedaan. Op deze manier wordt getracht de mogelijke ongewenste invloed van persoonsinformatie over de verdachte, zoals een strafblad en psychische problemen, te beperken. ${ }^{87}$ Op deze manier kan worden voorkomen dat irrelevante informatie voor de bewijsbeslissing toch, wellicht onbewust, een rol speelt bij de bewijsbeslissing. Toekomstig (experimenteel) onderzoek naar een dergelijk tweefasenmodel zal dit moeten uitwijzen. 


\section{Tot slot}

Ondanks dat in ongeveer $30 \%$ van de ernstige strafzaken die voor de meervoudige kamer komen een PJ-rapportage wordt opgesteld, ${ }^{88}$ is in Nederland verrassend weinig empirisch onderzoek gedaan naar het gebruik en de effecten van de informatie in deze rapportages op verschillende beslissingen die een rechter in het strafproces dient te nemen. De huidige studie heeft getracht om het gebruik van deze informatie te toetsen bij de eerste beslissing volgens het beslismodel van artikel 350 Sv. De informatie in een PJ-rapportage is formeel irrelevant voor de bewijsbeslissing. Deze empirische verkenning heeft echter laten zien dat informatie over een aanwezige psychische stoornis resulteert in een significant sterkere overtuiging van schuld en als gevolg daarvan in meer positieve bewijsbeslissingen. Voor de toekomst is het van belang om dit effect nader te bestuderen om na te gaan of dit effect verschilt voor verschillende stoornissen en delicten. Op deze manier ontstaat meer inzicht in welke factoren van belang kunnen zijn bij de overtuiging van de rechter bij een bewijsbeslissing, wat van belang kan zijn voor de legitimiteit van deze beslissingen.

\section{Referenties}

American Psychiatric Association, Diagnostic and Statistical Manual of Mental Disorders (DSM-5 ${ }^{\circledR}$ ), Michigan: American Psychiatric Association 2013.

Angermeyer, M.C. \& S. Dietrich, 'Public beliefs about and attitudes towards people with mental illness: A review of population studies', Acta Psychiatrica Scandinavica 2006-113(3), p. 163-179.

Ask, K. \& P.A. Granhag, 'Motivational sources of confirmation bias in criminal investigations: The need for cognitive closure', Journal of Investigative Psychology and Offender Profiling 2005(2), p. 43-63.

Atzmüller, C. \& P.M. Steiner, 'Experimental vignette studies in survey research', Methodology 2010-6(3), p. 128-138.

Berryessa, C.M. \& B. Wohlstetter, "The psychopathic "label" and effects on punishment outcomes: A meta-analysis', Law and Human Behavior 2019-43(1), p. 9-25.

Bijleveld, C.C.J.H. \& H. Elffers, 'Sekse en straftoemeting. Een experiment', Tijdschrift voor Criminologie 2010-52(4), p. 365-373.

Blanca, M.J., R. Alarcón, J. Arnau, R. Bono \& R. Bendayan, 'Non-normal data: Is ANOVA still a valid option?', Psicothema 2017-29(4), p. 552-557.

Claessen, J.A.A.C. \& D. de Vocht, 'Straf naar mate van schuld?', Delikt en Delinkwent 2012-63(7), p. 652-674.

Crombag, H.F.M., P.J. van Koppen \& W.A. Wagenaar, Dubieuze zaken: De psychologie van strafrechtelijk bewijs, Amsterdam: Contact 2005.

Devine, D.J. \& D.E. Caughlin, 'Do they matter? A meta-analytic investigation of individual characteristics and guilt judgments', Psychology, Public Policy, and Law 2014-20(2), p. 109-134. 
Dijk, A.A. van, E. Gritter, B.F. Keulen, N.J.M. Kwakman \& K. Lindenberg, Naar een tweefasenproces? Over voor- en nadelen van een strafproces in twee fasen, in relatie tot de posities van slachtoffer en verdachte, Zutphen: Paris 2012.

Dubelaar, M.J., Betrouwbaar getuigenbewijs: Totstandkoming en waardering van strafrechtelijke getuigenverklaringen in perspectief, Den Haag: Kluwer 2014.

Epstein, S., 'Integration of the cognitive and the psychodynamic unconscious', American Psychologist 1994-49(8), p. 709-724.

Es, R.M.S. van, M.J.J. Kunst \& J.W. de Keijser, 'Forensic mental health expert testimony and judicial decision-making: A systematic literature review', Aggression \& Violent Behavior 2020-51, 101387.

Esch, C.M. van, Gedragskundigen in strafzaken, Assen: Van Gorcum 2012.

Goodman-Delahunty, J. \& S.L. Sporer, 'Unconscious influences in sentencing decisions: A research review of psychological sources of disparity', Australian Journal of Forensic Sciences 2010-42(1), p. 19-36.

Gunnell, J.J. \& S.J. Ceci, 'When emotionality trumps reason: A study of individual processing style and juror bias', Behavioral Sciences \& the Law 2010-28(6), p. 850-877.

Fazel, S. \& J. Danesh, 'Serious mental disorder in 23000 prisoners: A systematic review of 62 surveys', Lancet 2002-359(9306), p. 545-550.

Fazel, S., G. Gulati, L. Linsell, J.R. Geddes \& M. Grann, 'Schizophrenia and violence: Systematic review and meta-analysis', PLoS Medicine 2009-6(8), e1000120.

Field, A., Discovering statistics using IBM SPSS statistics (5th ed.), London: SAGE 2018.

Fisher, T., 'Constitutionalism and the criminal law: Rethinking criminal trial bifurcation', University of Toronto Law Journal 2011- 61(4), p. 811-843.

Hastie, R., Inside the juror: The psychology of juror decision making, Cambridge University Press 1993.

Hayes, A.F., Introduction to mediation, moderation, and conditional process analysis: A regression-based approach, New York: Guilford Publications 2017.

HR 10 september 1957, ECLI:NL:HR:1957:2.

HR 9 december 2008, ECLI:NL:HR:2008:BD2775.

Hughes, R. \& M. Huby, 'The construction and interpretation of vignettes in social research', Social work \& Social Sciences Review 2004-11(1), p. 36-51.

Kahneman, D. \& A. Tversky, 'Subjective probability: A judgment of representativeness', Cognitive Psychology 1972-3(3), p. 430-454.

Kalven, H. \& H. Zeisel, The American jury, Boston, MA: Little, Brown 1966.

Kassin, S.M. \& H. Sukel, 'Coerced confessions and the jury: An experimental test of the "Harmless Error" rule', Law and Human Behavior 1997-21(1), p. 27-46.

Keijser, J.W. de, Als de waarheid eraan moet geloven: Alledaagse bedreigingen voor waarheidsvinding in het strafproces, Den Haag: Boom juridisch 2017.

Keijser, J.W. de \& P.J. van Koppen, 'Compensatoir straffen: Over de relatie tussen bewijs, overtuiging en straf', in: J.W. de Keijser \& H. Elffers (red.), Het maatschappelijke oordeel van de rechter: De wisselwerking tussen rechter en samenleving, Den Haag: Boom 2004, p. 133-183.

Koppen, P.J. van, 'Weg van de toerekeningsvatbaarheid: Over rapportages over de verdachte', Trema 2004-27, p. 221-228.

Kordelaar, W.F.J.M. van, Beslissingsondersteuning onderzoek Geestvermogens in het strafrecht voor volwassenen, Deventer: Kluwer 2002.

Laan, P. van der, J. van Busschbach \& C. Bijleveld, 'Experimentele criminologie en criminologische experimenten', Tijdschrift voor Criminologie 2007-49(1), p. 3-11. 
Mazzella, R. \& A. Feingold, 'The effects of physical attractiveness, race, socioeconomic status, and gender of defendants and victims on judgments of mock jurors: A metaanalysis', Journal of Applied Social Psychology 1994-24(14), p. 1315-1338.

Mitchell, T.L., R.M. Haw, J.E. Pfeifer \& C.A. Meissner, 'Racial bias in mock juror decisionmaking: A meta-analytic review of defendant treatment', Law and Human Behavior 2005-29(6), p. 621-637.

Mossière, A. \& E.M. Maeder, 'Defendant mental illness and juror decision-making: A comparison of sample types', International Journal of Law and Psychiatry 2015-42/43, p. 58-66.

Mowle, E.N., J.F. Edens, J.W. Clark \& K. Sorman, 'Effects of mental health and neuroscience evidence on juror perceptions of a criminal defendant: The moderating role of political orientation', Behavioral Sciences \& the Law 2016-34(6), p. 726-741.

Muller, E. \& M. Kempes, 'Gender differences in a Dutch forensic sample of severe violent offenders', International Journal of Forensic Mental Health 2016-15(2), p. 1-10.

Nederlands Instituut voor Forensische Psychiatrie en Psychologie, Jaarbericht 2019, Den Haag: Dienst Justitiële Inrichtingen 2020.

Nederlands Instituut voor Forensische Psychiatrie en Psychologie, Richtlijn ambulant forensisch psychologisch onderzoek en rapportage in het strafrecht (volwassenen en jeugdigen), Den Haag: Dienst Justitiële Inrichtingen 2016.

Nederlandse Vereniging voor Psychiatrie, Richtlijn psychiatrisch onderzoek en rapportage in strafzaken, Utrecht: De Tijdstroom 2013.

Newhill, C.E., S.M. Eack \& E.P. Mulvey, 'Violent behavior in borderline personality', Journal of Personality Disorder 2009-23(6), p. 541-554.

Nickerson, R.S., 'Confirmation bias: A ubiquitous phenomenon in many guises', Review of General Psychology 1998-2(2), p. 175-220.

Onderzoeksraad voor Veiligheid, Forensische zorg en veiligheid: Lessen uit de casus Michael P., Den Haag: Ministerie van Binnenlandse Zaken en Koninkrijksrelaties 2019.

Pennington, N. \& R. Hastie, 'Explaining the evidence: Tests of the story model for juror decision making', Journal of Personality and Social Psychology 1992-62(2), p. 189-206.

Pennington, N. \& R. Hastie, 'Reasoning in explanation-based decision making', Cognition 1993-49(1-2), p. 123-163.

Rassin, E., 'Initial evidence for the assimilation hypothesis', Psychology, Crime \& Law 201723(10), p. 1010-1020.

Ruiter, C. de, 'Gedragskundige rapportage bij een ontkennende verdachte: Niet zo onschuldig als het lijkt', GZ-Psychologie, 2010-5, p. 20-26.

Schillemans, T. \& I. Giesen, 'De kwaliteit van (juridische) oordelen: Verslag van een experiment over verantwoording, bias en de kwaliteit van beoordelingen bij toezichthouders en in de rechtspraak', Nederlands Juristenblad 2020-3, p. 182-193.

Simon, D., 'A third view of the black box: Cognitive coherence in legal decision making', The University of Chicago Law Review 2004-71, p. 511-586.

Sniderman, P.M. \& D.B. Grob, 'Innovations in experimental design in attitude surveys', Annual Review of Sociology 1996-22, p. 377-399.

Tversky, A. \& D. Kahneman, 'Judgment under uncertainty: Heuristics and biases', Science 1974-185(4157), p. 1124-1131.

Vinkers, D.J., E. de Beurs, M. Barendregt, T. Rinne \& H.W. Hoek, 'The relationship between mental disorders and different types of crime', Criminal Behaviour and Mental Health 2011-21, p. 307-320.

Wermink, H.T., S.G.W. van Wingerden, J.A. van Wilsem \& P. Nieuwbeerta, Etnisch gerelateerde verschillen in de straftoemeting. Research Memoranda - Raad voor de Rechtspraak nr. 10-1/2015, Den Haag: Raad voor de Rechtspraak-Sdu Uitgevers BV 2015. 